\title{
Trophallactic chains in honeybees: a quantitative approach of the nectar circulation amongst workers ${ }^{1}$
}

\author{
Joaquín GOYRET*, Walter M. FARINA** \\ Grupo de Estudio de Insectos Sociales, Departamento de Fisiología, Biología Molecular y Celular, \\ IFIB YNE-CONICET, Facultad de Ciencias Exactas y Naturales, Universidad de Buenos Aires, Pabellón II, \\ Ciudad Universitaria (C1428EHA), Buenos Aires, Argentina
}

Received 2 May 2005 - revised 16 May 2005 - accepted 24 May 2005

Published online 19 October 2005

\begin{abstract}
In honeybees, the rate at which a nectar forager unloads its crop to a receiver is positively correlated with the reward conditions the forager has recently experienced outside the hive. Food-receiver bees often share the nectar they have received with hive mates. A quantitative analysis of two consecutive trophallactic events was done in experimental arenas to determine if the food-transfer behavior of a foodreceiver as she distributes nectar to her hive mates is affected by her prior trophallactic experience with a donor forager. We found that the rate at which a receiver unloads nectar to another receiver is positively correlated with the rate at which she received it from a food donor, suggesting that it is possible to propagate, through individual-to-individual interactions, information about quantitative aspects of the liquid food circulating among worker honeybees.
\end{abstract}

Apis mellifera / trophallaxis / unloading rate / communication

\section{INTRODUCTION}

Honeybees display complex organization in their acquisition of nectar. This collective task involves the participation of at least two agerelated sub-groups of workers, foragers and younger receiving hive mates (Ratnieks and Anderson, 1999). When a nectar forager returns from a successful foraging trip, she directly transfers the collected crop contents to receiver hive mates by trophallaxis. Receiverbees share through subsequent trophallaxes the incoming liquid food, which begins to circulate inside the hive as a result of the trophallactic chains, in which the fresh nectar is partitioned among several hive members (Ribbands, 1955). A rapid distribution of nectar has been documented by Nixon and Ribbands (1952), who used radioactive sugar solution to quantify the rate at which the labeled nectar was shared inside the hive. Nectar partitioning can be interrupted by hive bees once they begin to handle the nectar for honey processing, when they deposit it into honey cells (Park, 1925; Winston, 1987). The propagation of this resource within the hive might be affected by several factors, including nectar influx, levels of food storage, time of the year and hive population, among others (Free, 1959; Istomina-Tsvetkova, 1960).

All social behavior is an outcome of individual behaviors (Dethier, 1962). At the level of the trophallactic interaction, several correlations have been described between nectar availability and trophallactic parameters. For instance, the temperature of foraging bees and the transfer-rate of their nectar unloadings are

* Current address: Department of Biological Sciences, Coker Life Sciences Building, 700 Sumter Street, University of South Carolina, Columbia, South Carolina 29208, USA.

** Corresponding author: walter@fbmc.fcen.uba.ar

${ }^{1}$ Manuscript editor: Marla Spivak 
positively correlated to the nectar flow rate at the source (Farina and Núñez, 1991; Farina and Wainselboim, 2001). From the side of nectar receivers, these bees warm up faster while receiving food from foragers returning from higherprofitable sources (Farina and Wainselboim, 2001). This evidence, together with the changes observed in the in-hive behaviors of food-receivers according to nectar availability (Pírez and Farina, 2004), suggest that individual-to-individual interactions are crucial during the acquisition of liquid resources in honeybees.

However, information is scarce on the interface between nectar unloading, which involves the nectar foragers as food donors, and nectar propagation at the social level. The way by which liquid food circulates among individuals in quantitative terms, and the presence of any correlations between trophallactic parameters within a chain of successive oral contacts would yield new information on how nectar circulates among hive mates. To answer this question, a quantitative analysis of two consecutive trophallactic interactions was done in experimental arenas used successfully in previous studies (Farina and Núñez, 1991).

\section{MATERIALS AND METHODS}

This study was carried out in April 2001 and repeated in April 2002. Each year we used a different one-frame observation hive with about 2000 honeybees Apis mellifera L., which had a queen and brood, as well as food reserves.

In both seasons, forager bees were trained to collect unscented $50 \%(\mathrm{w} / \mathrm{w})$ sucrose solution from an artificial feeder, placed $5 \mathrm{~m}$ from the hive entrance which delivered a constant flow rate of $120 \mu \mathrm{L} / \mathrm{min}$. After a group of bees were trained to this feeder, each experimental day began with a period of 1 hour at 9:00 am, when foragers could exploit the experimental feeder. Thereafter, the experimental foragers and their hive mates were captured to begin the trophallactic assays (see below).

\subsection{Procedure}

To capture empty workers, foragers were trapped at the rate-feeder before they began to drink. Potential receiver hive bees were captured in the area where the majority of the trophallactic interactions occurred within the hive (henceforth: delivery area, after Seeley, 1989). These bees were captured using a sliding acrylic wall that created a vertical aperture $(3.5 \mathrm{~cm}$. width) from the bottom to the top of the comb. This device could be moved from horizontally, from side to side, allowing us to scan the whole area of the exposed face of the hive. Vertical, up and down scanning was performed by separating two sliding acrylic pieces $(3 \times 27 \mathrm{~cm})$ over the aperture, creating a hole along any point of the vertical aperture. With a test-tube a chosen bee was isolated, captured and carried to the lab. Hive bees were removed from the delivery area; therefore, we can only surmise that these bees were hive-bees.

\subsection{Trophallactic assays}

Each trophallactic assay consisted of two consecutive trophallactic events performed in an experimental arena. The arena consisted of a rectangular box $(5.5 \times 5 \times 2 \mathrm{~cm})$ divided by a sliding door. Two plastic vials $(1 \mathrm{~cm}$ diameter $\times 2 \mathrm{~cm}$ long) containing each trophallactic partner were attached to opposite walls of the arena. Each vial also had a sliding door to retain the bees (see Farina and Núñez, 1991). The first trophallactic event involved a forager captured at the rate feeder which was fed until satiation in the lab (first order donor), while the trophallactic partner was captured at the delivery area of the hive and maintained unfed to stimulate the hive bees to act as receivers (first order receiver). If food transfer occurred, the second trophallactic event began. This event involved the first order receiver, now acting as a second order donor. A second hive bee captured in the same way at the delivery area of the hive, acted as the second order receiver. With this experimental design we could look for correlations in trophallactic behaviors between the first and the second trophallactic events. We tested the reliability of the following null hypothesis: the dynamics of food unloading in a trophallactic interaction (i.e. unloading rate) do not affect the unloading dynamics of subsequent trophallaxis interactions, in which the former receiver bee transfers the solution to another hive mate.

\subsection{Data collection and behavioral variables}

We allowed a maximum observation period of $10 \mathrm{~min}$ for the oral contact to occur. If no contact was observed during this period, the main sliding door was closed and the bees discarded. Donor foragers were weighed to the nearest $0.01 \mathrm{mg}$ after having been fed to satiation through a graduated capillary. Receptor bees were weighed without having been fed, and discarded if they weighed more than $85 \mathrm{mg}$ (assuming that for higher weights considerable amounts of food could be found in bees' crops). After each trial both donors and receivers were 
weighed again to obtain the quantity of transferred solution for each trial.

We recorded the following values: (1) trophallactic time, defined as the time spent engaged in the food exchange; (2) exchanged volume, defined as the mean difference between final and initial weights of the two bees divided by specific weight of solution; and (3) trophallactic responsiveness, defined as the number of the first or second trials with trophallaxis $\times 100 /$ number of total trials (with or without trophallaxis). Using the Exchanged volume $(\mu \mathrm{L})$ and the trophallactic time (s), we calculated the Unloading rate in $\mu \mathrm{L} / \mathrm{s}$.

\section{RESULTS}

Crop loads unloaded by donor foragers were similar for both hives (Fig. 1). However, trophallactic responsiveness abruptly changed when the two colonies were compared. For hive $1,100 \%$ of the trials (first and second trophallactic events) resulted in effective food transfers, while in hive 2 , trophallactic responsiveness fell to $85 \%$ in the first trial and $67 \%$ in the second one.

The time engaged in trophallaxis (trophallactic time) showed similarities between both hives. In hive 1 , the mean value of this variable ranged from $10-14 \mathrm{~s}$, and from 8-13 s in hive 2 (Fig. 1). Mean exchanged volumes were also similar for the two hives; during the first trophallactic event, bees from hive 1 exchanged a mean of $14.3 \mu \mathrm{L}$ and bees from hive 2 exchanged a mean of $11.7 \mu \mathrm{L}(t$-value $=1.07$; NS). During second trophallactic events, these values were $6.7 \mu \mathrm{L}$ and $4.9 \mu \mathrm{L}$ for hive 1 and 2 respectively $(t$-value $=1.36$; NS). In terms of percentage of volume exchanged, donor foragers transferred $25 \%$ of the ingested solution to hive bees in hive 1 and $21 \%$ in hive 2 . These hive bees, when acting as donors later unloaded $47 \%$ and $42 \%$ of the received solution in hive 1 and 2, respectively. With regards to this variable we found a positive correlation between the first and the second trophallactic event for hive 1 (Tab. I).

The rate at which foragers unloaded their crops to receiver bees (unloading rate during first trophallactic event) was statistically different between hives 1 and 2 (Fig. $1 ; t$-value = 2.13; $P=0.04)$. However, the decrease in the unloading rates of the second trophallactic events with respect to the first events was sim- ilar for both hives; they were approximately $60 \%$ of the unloading rates attained during the first trophallactic events (61.4\% and $65.5 \%$ for hive 1 and 2 respectively).

When comparing unloading rates achieved in the first and second trophallactic events, significant positive correlations were found for both hives (Tab. I). However, no correlation was observed between unloading rates in the second trophallactic events with any other variable recorded during the first trophallactic events such as trophallactic times (data not shown) and exchanged volumes (Tab. I).

\section{DISCUSSION}

Despite the difficulties in replicating this type of experiment and the artificial conditions in which they were performed, it was surprising how consistent the trophallactic parameters were throughout the experimental periods. Trophallactic times, exchanged volumes and unloading rates showed remarkable similarities, especially in relative terms, for both hives and/or years when the passage of food within a chain of individuals was analyzed.

In the first trophallactic event, hive bees received around $25 \%$ of the crop carried by donor foragers and transferred around $45 \%$ of their crop load to another hive mate. Also, the mean values of the unloading rate decreased in the same proportion after two consecutive trophallaxes. Second unloading rates were 35$40 \%$ lower compared to the first food transfers, despite the fact that the initial crop load of the second order donor was reduced by $75 \%$ compared with the first donor partner. Regardless of the lower unloading rates achieved after two consecutive trophallaxes, a correlation between the rate at which the nectar was received and the rate at which this solution was transferred, was found in both hives. This correlation allowed us to postulate that hive bees that have no direct contact with a successful incoming forager, could receive input about quantitative properties of the outside nectar source by means of the nectar circulating through mouthto-mouth interactions. Since this dynamic parameter was fairly conservative, we could conclude that quantitative aspects related to nectar source profitability, such as its flow rate, might be transferred to several individuals 


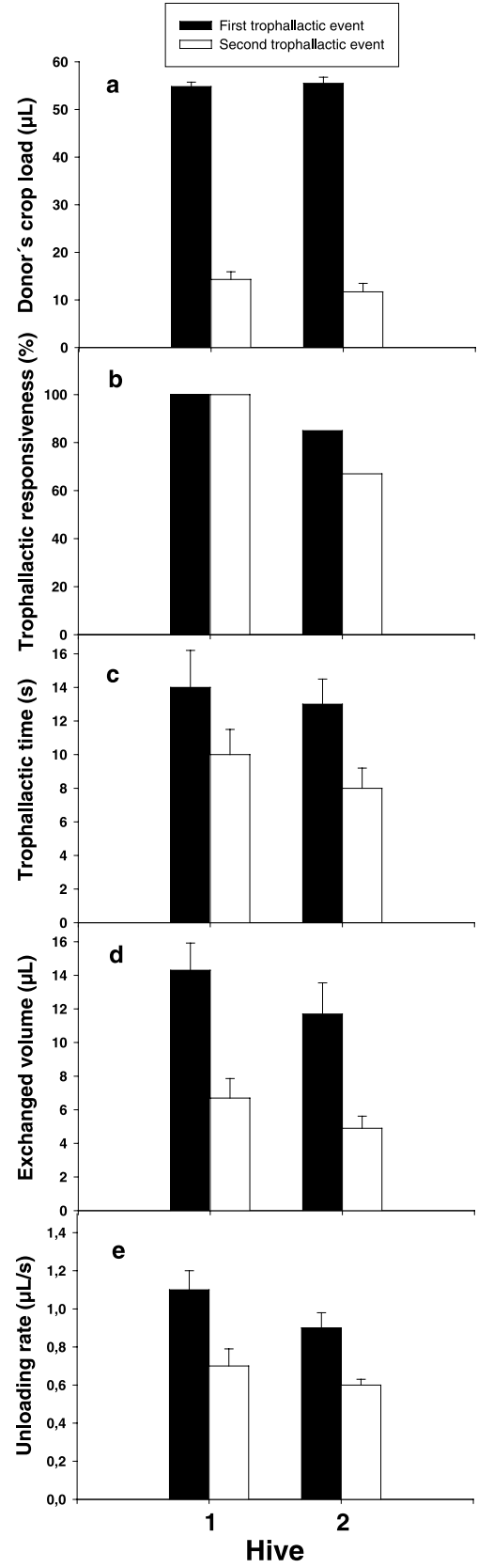

Figure 1. Crop-load values of food-donors and trophallactic parameters recorded at the arena for the two experimental hives analyzed. The first trophallactic event (black bars) involved a first order donor (a forager) fed through a graduated capillary up to satiation and a first order receiver (a hive bee) captured at the delivery area of the hive. In the second trophallactic event (white bars) the first order receiver was involved as a second order donor when confronted with another hive bee captured in the same area as in the first trophallactic event. (a) Donor's crop load, in $\mu \mathrm{L}$; (b) Trophallactic responsiveness, in \%; (c) trophallactic time, in s; (d) exchanged volume, in $\mu \mathrm{L}$; (e) unloading rate, in $\mu \mathrm{L} / \mathrm{s}$. The donor's crop load of the first order receiver was obtained from Exchanged volume in First trophallactic event. Number of replicates for each assay: 14. Analysis of variance between assays was not performed in order to avoid pseudoreplication. without direct contact with the first food unloader. The unloading rate of food-donor foragers correlated well with their foraging experience (Farina and Núñez, 1991; Wainselboim and Farina, 2000). On the basis of these results it was proposed that the unloading rate would be one of the putative trophal- lactic parameters involved in the behavioral changes observed after receiving nectar from different food source profitabilities (Farina and Wainselboim, 2001; Pírez and Farina, 2004).

Thus, hive bees, which were not directly involved in receiving nectar, may match their activity level to the activity level of the incoming 
Table I. Pearson's r-values between Exchanged volumes $(E v)$ and Unloading rates $(U r)$ from first and second trophallactic events of the two hives. 14 is the number of replicates per assay and for each hive.

\begin{tabular}{|c|c|c|c|c|}
\hline & \multicolumn{2}{|c|}{ Hive 1} & \multicolumn{2}{|c|}{ Hive 2} \\
\hline & $\begin{array}{c}E v \\
\text { (1 st event) }\end{array}$ & $\begin{array}{c}\text { Ur } \\
\text { (1st event) }\end{array}$ & $\begin{array}{c}E v \\
(1 \text { st event })\end{array}$ & $\begin{array}{c}U r \\
\text { (1 st event) }\end{array}$ \\
\hline $\begin{array}{c}E v \\
\text { (2nd event) }\end{array}$ & $\begin{array}{c}\mathrm{r}=0.59 \\
P=0.0023\end{array}$ & NS & NS & NS \\
\hline $\begin{array}{c}U r \\
\text { (2nd event) }\end{array}$ & NS & $\begin{array}{c}\mathrm{r}=0.56 \\
P<0.0001\end{array}$ & NS & $\begin{array}{c}\mathrm{r}=0.79 \\
P=0.0034\end{array}$ \\
\hline
\end{tabular}

foragers, such as was reported for the firstorder receivers inside the hive (Pírez and Farina, 2004). Thus, an increasing activity level could propagate through mouth-to-mouth interactions, which may allow hive bees to adjust their foraging-related tasks in accordance to the incoming resource profitability. In this sense, it was recently reported that sucrose responsiveness of pre-forager hive bees rapidly changed according to the sugar concentration circulating inside the hive (Pankiw et al., 2004).

Differences were found, however, in both seasons and/or hives regarding trophallactic responsiveness and unloading rates. Unfortunately, the bees' foraging activity at natural sources was not quantified, but it was clear that the activity of hive 2 was much more intense than that of hive 1 (Goyret: personal observation). Perhaps current foraging levels alter these trophallactic parameters but we do not have enough information to determine this putative relationship.

From these results it could also be concluded that hive bees retained lower crop loads after transferring food than did foragers, a fact that would be functional within the hive to reload their crops with samples of nectar from new incoming foragers. Moreover, the high trophallactic responsiveness found suggested that hive bees are much more appropriate to be used as receiver partners than emptied foragers, as was concluded in previous related studies (Farina and Núñez, 1991; Wainselboim and Farina, 2000). Because we used hive bees taken from the delivery area, these results suggest that the probability of establishing trophallaxis in experimental arenas depends on a forager encountering a trophallactic partner of the correct subtask group.

\section{ACKNOWLEDGMENTS}

We thank two anonymous referees for valuable comments on the early version of this manuscript and M. Spivak for language help. This study was supported by funds from Fundación Antorchas, ANPCYT (PICT 02-12310), the University of Buenos Aires (X036) and CONICET (PIP 2049) to WMF. The present study complies with the current laws of the state country in which experiments were performed.

Résumé - Les chaînes trophallactiques chez les abeilles domestiques : approche quantitative de la circulation du nectar parmi les ouvrières. Lorsqu'une abeille (Apis mellifera L.) rentre d'un vol de butinage fructueux, elle décharge le contenu de son jabot auprès de receveuses situées dans la ruche. Le nectar qui arrive est souvent partagé par trophallaxie et il commence ainsi à circuler à l'intérieur de la ruche. Il résulte de ces chaînes trophallactiques que le nectar est réparti entre les membres de la colonie. Des études antérieures ont montré que le taux de déchargement de la récolte d'une butineuse à une receveuse est positivement corrélé avec les conditions de récompense que la butineuse a récemment expérimentées hors de la colonie. Cet article présente une analyse quantitative de deux épisodes trophallactiques successifs. Elle a été réalisée dans des enceintes expérimentales afin de savoir si le comportement de transfert de nourriture d'une receveuse, quand elle distribue le nectar à ses consoeurs, est affecté par son expérience trophallactique antérieure avec une donneuse.

Les paramètres de la trophallaxie (durée de la trophallaxie, volumes échangés et taux de déchargement) sont restés uniformes au cours des expériences. Ces paramètres ont présenté des similitudes remarquables, particulièrement en termes relatifs, pour les deux colonies et/ou années lorsqu'a été analysé le passage de la nourriture au sein d'une chaîne d'individus. Au cours du premier épisode de trophallaxie, les abeilles de la ruche ont reçu environ $25 \%$ de la récolte rapportée par les butineuses donneuses et en ont transféré environ $45 \%$ à une consoeur. Le taux de déchargement a diminué dans la même proportion 
après deux trophallaxies successives. Les seconds taux de déchargement étaient 35 à $40 \%$ plus bas que les premiers transferts, bien que la charge initiale de la seconde donneuse fût réduite de $75 \%$ par rapport à la première. Mis à part les taux plus faibles de déchargement après deux trophallaxies successives, on a trouvé dans les deux ruches une corrélation entre le taux de réception du nectar et son taux de transfert. Cette corrélation nous permet d'émettre l'hypothèse que les abeilles d'intérieur, bien que n'ayant pas de contact direct avec la butineuse qui rentre, pourraient recevoir des données concernant l'aspect quantitatif de la source extérieure de nectar grâce à la circulation de nourriture à l'intérieur de la ruche.

Apis mellifera / trophallaxie / taux de déchargement / communication

Zusammenfassung - Futterweitergabeketten bei Honigbienen: ein quantitativer Ansatz bei der Nektarzirkulation im Volk. Wenn eine Honigbiene von einem erfolgreichen Trachtflug zurückkehrt, gibt sie den Inhalt ihres Honigmagens an Empfängerbienen weiter. Diese Stockbienen verteilen den hereinkommenden Nektar durch Trophallaxis, wodurch dieser im Volk zu zirkulieren beginnt. Als Ergebnis dieser trophallaktischen Ketten wird frisch eingetragener Nektar unter mehreren Volksmitgliedern verteilt. Bisherige Untersuchungen zeigen, dass die Rate, mit der die Sammlerin ihren Mageninhalt an eine Empfängerbiene weitergibt, positiv mit der Ergiebigkeit der besuchten Futterquelle korreliert. Zur Klärung der Frage, ob das Verhalten einer Empfängerbiene bei der Futterweitergabe an Volksgenossen durch ihre vorherige Erfahrung mit der Geberbiene beeinflusst wird, wurde in Versuchsarenen eine quantitative Analyse von zwei aufeinander folgenden Futterübertragungen durchgeführt. Trophallaktische Parameter wie die Dauer der Fütterung, die weitergegebene Futtermenge und die Rate der Futterabgabe waren über die Dauer der Versuchszeit gleichmäßig verteilt. Bei der Analyse der Weitergabe von Futter innerhalb einer Kette von Einzeltieren waren diese Parameter bei beiden Völkern und Versuchsjahren von bemerkenswerter Einheitlichkeit, besonders wenn sie als relative Werte gefasst waren. Bei den ersten trophallaktischen Ereignisse erhielten die Stockbienen etwa $25 \%$ des Mageninhalts der Geberbienen, diese gaben dann etwa $45 \%$ ihres Mageninhalts an andere Stockgenossinnen weiter. Die Rate der Weitergabe nahm bei zwei nachfolgenden Fütterungen in gleichen Proportionen ab. Bei der zweiten Futterweitergabe ergaben sich mit 35-40\% niedrigere Werte als bei der ersten Abgabe, obwohl die ursprüngliche Magenladung der zweiten Geberbiene im Vergleich zum ersten Geberpartner um $75 \%$ reduziert war. Ungeachtet der nach zwei aufeinanderfolgenden Fütterungen niedrigeren Fütterungsrate ergab sich bei beiden Völkern eine
Korrelation zwischen der Rate der Nektaraufnahme und der Rate der Weiterverteilung dieser Lösung. Diese Korrelation erlaubte uns zu postulieren, dass Stockbienen, auch wenn sie keinen direkten Kontakt mit den Sammelbienen haben, die quantitativen Eigenschaften der Futterquelle anhand der Futterverteilung innerhalb des Stocks wahrnehmen können.

Apis mellifera / Trophallaxis / Abgaberate / Kommunikation

\section{REFERENCES}

Dethier V.G. (1962) To Know a Fly, Holden-Day, Inc.

Farina W.M., Núñez J.A. (1991) Trophallaxis in the honeybee Apis mellifera L. as related to the profitability of food sources, Anim. Behav. 42, 389-394.

Farina W.M., Wainselboim A.J. (2001) Changes in the thoracic temperature of honeybees while receiving nectar from foragers collecting at different reward rates, J. Exp. Biol. 204, $1653-$ 1658.

Free J.B. (1959) The transfer of food between the adult members of a honeybee community, Bee World 40, 193-201.

Istomina-Tsvetkova K.P. (1960) Contribution to the study trophic relations in adult worker bees, XVII Int. Beekeeping Congr. Bologna-Roma, Vol. 2, Bucharest, Apimondia, pp. 361-368.

Nixon H.L., Ribbands C.R. (1952) Food transmission within the honeybee community, Proc. R. Soc. ser. B 140, 43-50.

Pankiw T., Nelson M., Page R.E., Fondrk M.K. (2004) The communal crop: modulation of sucrose response thresholds of pre-foraging honey bees with incoming nectar quality, Behav. Ecol. Sociobiol. 55, 286-292.

Park W. (1925) The storing and ripening of honey by honeybees, J. Econ. Entomol. 18, 405-410.

Pírez N., Farina W.M. (2004) Nectar-receiver behavior in relation to the reward rate experienced by foraging honeybees, Behav. Ecol. Sociobiol. 55, 574-582.

Ratnieks F.L.W., Anderson C. (1999) Task partitioning in insect societies, Insectes Soc. 46, 95-108.

Ribbands C.R. (1955) The scent language of Honey bees, Annu. Rep. Smithsonian Institution, 368377.

Seeley T.D. (1989) Social foraging in honeybees: how nectar foragers assess their colony's nutritional status, Behav. Ecol. Sociobiol. 24, 181-199.

Wainselboim A.J., Farina W.M. (2000), Trophallaxis in the honeybee Apis mellifera (L.): the interaction between flow of solution and sucrose concentration of the exploited food sources, Anim. Behav. 59, 1177-1185.

Winston M.L. (1987) Biology of the honey bee, Harvard Univ. Press, Cambridge. 